\title{
The Interest of Prospective Students in Study Programs in Higher Education: a Preliminary Study
}

\author{
Dian Cahyawati \\ Mathematics Education Dept. Universitas Pendidikan Indonesia, Bandung, Indonesia \\ Mathematics Dept. Universitas Sriwijaya, Palembang, Indonesia \\ dianc_mipa@unsri.ac.id
}

\begin{abstract}
The purpose of this research was to describe the interest of prospective students in study programs in public higher education in Indonesia. Data of enrollment selection participants to all public higher education were drawn from the official website SBMPTN in the year 2014. A number of samples were 37 of public higher education that was chosen by proportional random sampling according to the division of public higher education regions. Participants data was analyzed descriptively about that percentage of each study program in a field of science-and-technology and social-and-humanities. Furthermore, analyzed of the percentage and the probability ratio of prospective students who interested in mathematics education and pure mathematics. The results showed that the number of prospective students who interesting in a field of a science-and-technology tend to be greater than the number of them in a field of social-and-humanities. Medical Education, Informatics Engineering Education, and Civil Engineering were study programs that were interested in any region for the science-and-technology field. Elementary Teacher Education, English Study, Accounting, Law, and Management were study programs that were interested in any region for social-andhumanity field. The rank of Mathematics Education was always in the top position of the Pure Mathematics. The election probability of Mathematics Education came to be more greater then the election probability of Pure Mathematics.
\end{abstract}

Keywords-study program, enrollment test to public higher education, SBMPTN, odds ratio

\section{INTRODUCTION}

Education in Indonesia is one of the government programs in order to implement national development. One of the objectives of national development is mandated by the 1945 Constitution is the nation's intellectual life [1]. Therefore, there are clear rules for government in expansion and acceleration of educational opportunities in Indonesia [2]. Acquisition opportunities of education starting from a primary, a senior high school, to a higher education (HE) are given that everyone can have a preparation to face the challenges of the future. Getting higher education was perceived by Ukrainians to achieve professional distinction, economic independence [3]. Obtaining a higher education provides the opportunities for people protects themselves to against a poverty [4]. Government and public education institutions have keenly felt the responsibility of ensuring access to education [5]. The increasing of access to education is reflected in the increasing percentage of students enrolled in a relevant age group in undergraduate programs [6]. In efforts to expand an access and an opportunity study to HE needed to consider some influential factors.

One of those factors are students' demand [7] although that paper identified the challenges and the opportunities for enhancing higher education in entrepreneurship, but the results addressed challenges that cross borders. By paying attention to it, the expansion of study to HE will be in accordance with market need and the interest of students.

Therefore, it is necessary to find out the information on the interest of students in study programs in HE. The surveys of Programme for International Student Assessment (PISA) published about a field of science were chosen by tertiary students, gender differences in choosing fields of science, and field of science on study abroad [8]. The field of science in that studies used a grouping of sciences from the United Nations Educational Scientific and Cultural Organization (UNESCO) in 2012. Fields of sciences or study programs were grouped into 10 categories that came from 25 more specific study programs. The results of PISA survey showed that the social sciences, business, and law disciplines group were the most popular of fields of science in the first order preferred $(32 \%)$ that were based upon the number of the HE in a group of PISA memberships. The fields of science in second order $(15 \%)$ preferred were engineering, manufacturing, and construction [9].

Based on the same survey, the different result came in Finland and Korea, in the first order of fields of science that student preferred namely engineering, manufacturing, and construction, not a social science, business, and law. The difference occurred also in Belgium, fields of science that rank second in demand, not the engineering, manufacturing, and construction, but the field of health and welfare. The popularity degree of agriculture and services fields were under the popularity degree of all social sciences, business, law, engineering sciences, manufacturing, and construction fields.

In Indonesia, one way to obtain information on the interest of prospective students in study programs in public $\mathrm{HE}$ is studying data of its enrolment test participants who can be found on the official website https://www.sbmptn.or.id/. The results of this analysis are expected to be used by university's policymakers as consideration for increasing or decreasing the student capacity of a certain study program. The results are also expected to be used by government policymakers as consideration for planning the expansion of employment. Although the acquisition of a job does not guarantee for someone could be out of poverty, because there are still 
serious problems in the quality of work in Indonesia [10]. However, the synergy between the university policymakers and the government policymakers is expected to reduce the chances of educated unemployment whereas the educated unemployment is a serious problem in employment because the numbers are still large [11].

Based on that idea, to determine the interest of prospective students or their selection in a study program in HE, there should be an in-depth study and research. In addition, for some universities that they have educational and noneducational study programs such as mathematics education and pure mathematics study programs are interesting to take a note and to compare in terms of its demand. As a preliminary study, this research aimed to describe the distribution of the interest of prospective students in various existing study programs in public HE in Indonesia. Furthermore, to find out the probability ratio of the interest of prospective students in mathematics education and pure mathematics study programs based upon the differences in a senior high school background.

\section{RESEARCH METHOD}

Population in this study was all public HE in Indonesia that can be selected by the prospective students in national enrollment written test (SBMPTN) to a public HE in 2014. The numbers of public HE were 74 divided into four regions. The sample size was $50 \%$ (37 public HE) that used proportional random sampling technique based upon the region division. This sampling technique ensures each subspace can provide enough information [12]. The sample analysis was prospective students in each public HE.

The data source was obtained from the SBMPTN official website namely https://www.sbmptn.or.id/. Each of the study programs in public HE grouped into the fields of science-andtechnology (sci-tech) and social-sciences-and-humanities (sochum). The sci-tech field requires a natural science program background in senior high school while the soc-hum field requires a social science program background.

The data were analyzed descriptively in four stages. Firstly, calculated a number of prospective students in every sample of the public HE based on the sci-tech and the soc-hum fields. Secondly, found out the most preferred study programs based on its percentage. Thirdly, found out the rank of both of mathematics education and pure mathematics study programs in each region. Fourth, found out the probability ratio of the interest of prospective students in mathematics education and pure mathematics study programs based on their senior high school background using odds ratio values. The odds ratio is one kind of ratios very commonly used in biostatistics and research that is deceptively simple [13]. The values can be calculated by $\hat{\theta}=\frac{n_{11} n_{22}}{n_{12} n_{21}}$, with $n_{i j}$ is a cell count in an $2 \times$ 2 contingeny table [14].

\section{RESULT AND DISCUSSION \\ A. Public Higher Education in Indonesia}

Nowadays, the public higher education (HE) in Indonesia are using three types of enrollment test to select their prospective students. The first type, the selection is based upon the value of report cards, a national test score, and other academic achievements without the written test, namely National Selection of Public Higher Education (SNMPTN). The second type, the selection is based on the national written test, namely Joint Selection of Public Higher Education (SBMPTN). Lastly, the selection is based on a written test that is conducted independently by each higher education institution (USM).

There were 74 public HE in various regions that could be selected on SBMPTN in 2014 (https://www.sbmptn.or.id/). The public HE is grouped into four regions that based upon its location. The Region 1 includes all public HE that located in Sumatera, Jakarta, West Java, Banten and West Kalimantan. The Region 2 includes all public HE that located in Central Java and Yogyakarta. The Region 3 includes all public HE that located in East Java, Bali, West Nusa Tenggara, East Nusa Tenggara, and Kalimantan (except West Kalimantan). Lastly, The Region 4 includes all public HE that located in Sulawesi, Maluku, Ambon, Papua and West Papua. A number of public $\mathrm{HE}$ for each region and a number of its study programs are shown in Table 1.

\begin{tabular}{ccc}
\multicolumn{3}{c}{ Table 1. The Number of Public HE and } \\
Study Program \\
\hline Region & Public HE & Study Program \\
\hline 1 & 30 & 1069 \\
2 & 10 & 378 \\
3 & 20 & 702 \\
4 & 14 & 550 \\
\hline Total & 74 & 2699 \\
\hline & Reference: https://www.sbmptn.or.id/ (2015)
\end{tabular}

In the year 2014, there were 664,509 students who graduated from a senior high school that took the national written test to HE would become prospective students through the SBMPTN type [9]. The study programs were chosen by the prospective students scattered in Table 1, except for some new public HE there was still no demand.

A short description to the public HE sampled, a number of study programs in sci-tech and soc-hum field of studies, and a number of applicants for mathematics education and pure mathematics are shown in Table 2.

Universitas Pendidikan Indonesia (UPI) is a public HE in the Region 1 as the most number of study programs with 74 study programs in 2014. In the Region 2, Universitas Sebelas Maret (UNS) was the most number of study programs with 64 study programs. In the Region 3, Universitas Negeri Semarang (Unnesa) and Universitas Lambung Mangkurat (Unlam) were the most number of study programs with 60 study programs respectively. In the Region 4, Universitas Negeri, Makassar (UNM) was the largest number of study programs with 65 study programs. 
Table 2. The Short Description to Public HE Sampled

\begin{tabular}{|c|c|c|c|c|c|c|c|c|c|}
\hline \multirow{2}{*}{ No } & \multirow[b]{2}{*}{ Public HE } & \multicolumn{4}{|c|}{ Study Program } & \multicolumn{4}{|c|}{ Number of Prospective Students } \\
\hline & & Region & sci-tech & soc-hum & Total & sci-tech & soc-hum & $\begin{array}{c}\text { Math. } \\
\text { Education }\end{array}$ & $\begin{array}{l}\text { Pure } \\
\text { Math. }\end{array}$ \\
\hline 1 & Universitas Syiah Kuala & 1 & 36 & 22 & 58 & 24422 & 18953 & 679 & 213 \\
\hline 2 & Universitas Malukussaleh & 1 & 16 & 12 & 28 & 3992 & 3318 & 0 & NA \\
\hline 3 & Universitas Teuku Umar* & 1 & 7 & 4 & 11 & 0 & 0 & NA & NA \\
\hline 4 & Universitas Samudra* & 1 & 15 & 10 & 25 & 0 & 0 & 0 & 0 \\
\hline 5 & UIN Sutan Syarif Kasim & 1 & 9 & 7 & 16 & 3908 & 5280 & 521 & 130 \\
\hline 6 & Universitas Maritim Raja Ali & 1 & 9 & 8 & 17 & 1120 & 2357 & 153 & NA \\
\hline 7 & Universitas Sriwijaya & 1 & 33 & 17 & 50 & 26546 & 17747 & 642 & 268 \\
\hline 8 & Institut Tek,Sumatera* & 1 & 7 & - & 7 & 0 & 0 & NA & NA \\
\hline 9 & UIN Raden Fatah & 1 & 7 & 4 & 11 & 639 & 88 & 95 & NA \\
\hline 10 & Institut Pertanian Bogor & 1 & 37 & - & 37 & 33838 & 0 & NA & 477 \\
\hline 11 & Universitas Pendidikan Indonesia & 1 & 20 & 54 & 74 & 15231 & 35142 & 1188 & 555 \\
\hline 12 & Universitas Padjadjaran & 1 & 22 & 28 & 50 & 37146 & 40335 & NA & 837 \\
\hline 13 & UPN Veteran Jakarta* & 1 & 9 & 5 & 14 & 0 & 0 & 0 & 0 \\
\hline 14 & Universitas Siliwangi* & 1 & 8 & 12 & 20 & 0 & 0 & 0 & NA \\
\hline 15 & $\begin{array}{l}\text { Universitas Negeri Singaperbangsa } \\
\text { Karawang* }\end{array}$ & 1 & 6 & 9 & 15 & 0 & 0 & 0 & NA \\
\hline 16 & Universitas Jenderal Soedirman & 2 & 24 & 15 & 39 & 19861 & 14780 & NA & 476 \\
\hline 17 & Universitas Sebelas Maret & 2 & 21 & 43 & 64 & 10695 & 11613 & 1553 & 434 \\
\hline 18 & Universitas Diponegoro & 2 & 32 & 17 & 49 & 33442 & 21363 & NA & 526 \\
\hline 19 & UIN Walisongo* & 2 & 5 & 4 & 9 & 0 & 0 & NA & 0 \\
\hline 20 & Universitas Negeri Yogyakarta & 2 & 17 & 38 & 55 & 13006 & 29681 & 1563 & 788 \\
\hline 21 & Universitas Negeri Semarang & 3 & 19 & 41 & 60 & 11764 & 24142 & 1190 & 456 \\
\hline 22 & Institut Teknologi Sepuluh November & 3 & 28 & - & 28 & 25077 & 0 & NA & 441 \\
\hline 23 & Universitas Airlangga & 3 & 21 & 18 & 39 & 17639 & 18209 & NA & 688 \\
\hline 24 & UPN Veteran Jatim* & 3 & 11 & 8 & 19 & 0 & 0 & NA & NA \\
\hline 25 & Universitas Pendidikan Ganesha & 3 & 9 & 22 & 31 & 929 & 3127 & 210 & NA \\
\hline 26 & Universitas Mataram & 3 & 21 & 13 & 34 & 12215 & 19009 & 610 & 324 \\
\hline 27 & Universitas Timor* & 3 & 5 & 6 & 11 & 0 & 0 & 0 & NA \\
\hline 28 & Universitas Palangkaraya & 3 & 17 & 19 & 36 & 3515 & 4599 & 242 & NA \\
\hline 29 & Universitas Lambung Mangkurat & 3 & 37 & 23 & 60 & 10553 & 0 & 527 & 124 \\
\hline 30 & Institut Teknologi Kalimantan* & 3 & 10 & - & 10 & 0 & 0 & NA & 0 \\
\hline 31 & Universitas Negeri Makassar & 4 & 25 & 40 & 65 & 8586 & 26417 & 1164 & 321 \\
\hline 32 & Universitas Negeri Manado & 4 & 15 & 28 & 43 & 1917 & 3597 & 283 & NA \\
\hline 33 & Universitas Sulawesi Barat* & 4 & 11 & 6 & 17 & 0 & 0 & 0 & 0 \\
\hline 34 & Universitas Sembilan Belas November & 4 & 8 & 4 & 12 & 0 & 0 & 0 & NA \\
\hline 35 & Universitas Cenderawaasih & 4 & 20 & 17 & 31 & 6508 & 6840 & 146 & 50 \\
\hline 36 & Universitas Khairun & 4 & 17 & 14 & 31 & 3294 & 3142 & 251 & NA \\
\hline 37 & Universitas Papua & 4 & 18 & 7 & 25 & 1554 & 809 & 24 & 14 \\
\hline
\end{tabular}

Based on Table 2, there were 3 public HEs that did not have (NA) both of mathematics education and pure mathematics study programs; 19 public HEs did not have one of those study programs; 15 public HEs did not have both of mathematics education and pure mathematics study programs. The 15th public HEs were Universitas Syiah Kuala, Universitas Samudera, UIN Sultan Syarif Kasim, Universitas Sriwijaya, Universitas Pendidikan Indonesia, UPN Veteran Jakarta, Universitas Sebelas Maret, Universitas Negeri Yogyakarta, Universitas Negeri Semarang, Universitas Mataram, Universitas Lambung Mangkurat, Universitas Negeri Makassar, Universitas Sulawesi Barat, Universitas Cendrawasih, and Universitas Papua.

\section{B. The Interest of Prospective Students in Study Programs:} Public Higher Education in Indonesia

Each of the prospective students graduated from senior high school in 2014 who joined SBMPTN test they could choose one of the study programs in a field of sci-tech, a field of soc-hum, or both of them to register as mixed group examinees. Table 2 shows that the number of prospective students who chose a field of sci-tech was greater than the number of prospective students who chose a field of soc-hum in all the regions, except in the Region 4. 
C. The Interest of Prospective Students in Study Programs: A Field of Sci-Tech and Soc-Hum

The most preferred study programs in the SBMPTN test in 2014 for sci-tech group are shown in Table 3.

From the fourth regions in Table 3, a field of sci-tech acquired 21 study programs. From those 21 study programs, the study programs that exist in each of the regions were Medical Education, Informatics Engineering Education, and Civil Engineering.

The most preferred study programs in the SBMPTN test in 2014 for soc-hum group are shown in Table 4.

Table 3, The Most Preferred Study Programs in a Field of Sci-Tech

\begin{tabular}{cllll}
\hline \multirow{2}{*}{ No, } & \multicolumn{5}{c}{ Study Programs } \\
\cline { 2 - 5 } & \multicolumn{1}{c}{ Region 1 } & \multicolumn{2}{c}{ Region 2 } & \multicolumn{1}{c}{ Region 3 } \\
\hline 1 & Medical Education & Medical Education & Civil Engineering & Biology Education \\
2 & Pharmaceutical & Public Health & Medical Education & Mathematics Education \\
3 & Agribusiness & Civil Engineering & Informatics Engineering & Civil Engineering \\
4 & Informatics Engineering & Informatics Engineering & Mechanical Engineering & Physical education \\
5 & Civil Engineering & Biology & Electrical Engineering & Chemical Education \\
6 & Nursing Science & Informatics Engineering Education & Public Health & Medical Education \\
7 & Agroecotechnology & Science of Nutrition & Mathematics Education & Public Health \\
8 & Dentist Education & Mechanical Engineering & Biology Education & Sport Science \\
9 & Mining Engineering & Agribusiness & Biology & Informatics Engineering \\
10 & Geology Engineering & Geology Engineering & Information Systems & Mining Engineering \\
\hline
\end{tabular}

Table 4 shows the most preferred study programs in SBMPTN 2014 for soc-hum group. There were 15 study programs that include the first top ten of the study programs. The study programs that exist in all the regions were
Elementary Teacher Education, English Study, Accounting, Law, and Management.

Table 4. The Most Preferred Study Programs in A Field of Soc-Hum

\begin{tabular}{|c|c|c|c|c|}
\hline \multirow{2}{*}{ No, } & \multicolumn{4}{|c|}{ Study Programs } \\
\hline & Region 1 & Region 2 & Region 3 & Region 4 \\
\hline 1 & $\begin{array}{l}\text { Management } \\
\text { Communication }\end{array}$ & Management & Management & $\begin{array}{l}\text { Elementary Teacher } \\
\text { Education }\end{array}$ \\
\hline 2 & Studies & Accounting & $\begin{array}{l}\text { Accounting } \\
\text { Elementary Teacher }\end{array}$ & Management \\
\hline 3 & Accounting & $\begin{array}{l}\text { Law } \\
\text { The Science of Public }\end{array}$ & Education & $\begin{array}{l}\text { Accounting } \\
\text { English Language }\end{array}$ \\
\hline 4 & $\begin{array}{l}\text { Law } \\
\text { Elementary Teacher }\end{array}$ & Administration & $\begin{array}{l}\text { Law } \\
\text { English Language }\end{array}$ & $\begin{array}{l}\text { Education } \\
\text { Indonesian Language }\end{array}$ \\
\hline 5 & $\begin{array}{l}\text { Education } \\
\text { The Science of Public }\end{array}$ & $\begin{array}{l}\text { Communication Studies } \\
\text { Indonesian Language }\end{array}$ & Education & and Literature Education \\
\hline 6 & Administration & $\begin{array}{l}\text { and Literature Education } \\
\text { Economics and Develop }\end{array}$ & Communication Studies & Business Administration \\
\hline 7 & $\begin{array}{l}\text { Sociology } \\
\text { Economics and }\end{array}$ & $\begin{array}{l}\text { Studies } \\
\text { Elementary Teacher }\end{array}$ & $\begin{array}{l}\text { Psychology } \\
\text { Indonesian Language }\end{array}$ & Psychology \\
\hline 8 & Develop Studies & Education & $\begin{array}{l}\text { and Literature Education } \\
\text { Economics and Develop }\end{array}$ & Law \\
\hline 9 & $\begin{array}{l}\text { Psychology } \\
\text { English Language }\end{array}$ & $\begin{array}{l}\text { Counseling Guidance } \\
\text { English Language and }\end{array}$ & Studies & Geography Education \\
\hline 10 & Education & Literature & English Literature & Counseling Guidance \\
\hline
\end{tabular}

D. The Percentage Rank of the Prospective Students for Mathematics Education and Pure Mathematics Study Programs

In general, a mathematics education study program is organized by a faculty of education, while a pure mathematics study program is organized by a faculty of mathematics and natural science. A number of prospective students who interested in mathematics education always more than the number of prospective students who interested in pure mathematic in various public HE.
According to the percentage rating of prospective students, both of mathematics education and pure mathematics study programs have not been included in the top 10th ranked as a desirable study program in SBMPTN 2014. Table 5 displays the number and percentage of applicants' data as well as the rank of mathematics education and pure mathematics study programs. The percentage position on mathematics education study program is always in the top positions of pure mathematics study program in the various regions except in the Region 2. 
Table 5, Number of Applicant, Percentage, Ranked Mathematics Education and Pure Mathematics Study Programs in SBMPTN 2014

\begin{tabular}{|c|c|c|c|c|c|}
\hline \multirow{2}{*}{ No, } & \multirow{2}{*}{ Study Programs } & \multirow{2}{*}{ Region } & \multicolumn{2}{|c|}{ Applicants } & \multirow{2}{*}{ Ranked } \\
\hline & & & Total & Percentage & \\
\hline \multirow[t]{4}{*}{1} & Mathematics Education & 1 & 3278 & 2.2 & 15 \\
\hline & & 2 & 1563 & 2.0 & 19 \\
\hline & & 3 & 2779 & 3.4 & 10 \\
\hline & & 4 & 1868 & 8.5 & 2 \\
\hline \multirow[t]{4}{*}{2} & Pure Mathematics & 1 & 2480 & 1.7 & 23 \\
\hline & & 2 & 2224 & 2.9 & 12 \\
\hline & & 3 & 2033 & 2.5 & 14 \\
\hline & & 4 & 385 & 1.8 & 21 \\
\hline
\end{tabular}

E. The Probability Ratio of Prospective Students Interest in Mathematics Education and Pure Mathematics Study Programs based on various Senior High School Backgrounds.

Both prospective students of a mathematics education and pure mathematics study programs came from a different senior high school background. There were prospective students who came from a package's $\mathrm{C}$ class senior high school in natural science or social science (Paket C IPA/IPS), a senior high school in natural science or social science or languages (SMA IPA/IPS/Bahasa), a vocational in natural science or social science (SMK IPA/IPS), a Madrasah Aliyah in natural science or social science or religion $(M A$ IPA/IPS/Agama), or other senior high schools (https://www,sbmptn,or,id/, 2015). From the variety of backgrounds, the number of prospective students came dominantly from SMA IPA/IPS/Bahasa, SMK IPA/IPS, and MA IPA/IPS.

The number of prospective students came from those various senior high school backgrounds for a mathematics education and pure mathematics depicted in Fig 1. Based on the differences of a senior high school background the number of mathematics education prospective students tends to be more than the number of pure mathematics prospective students.

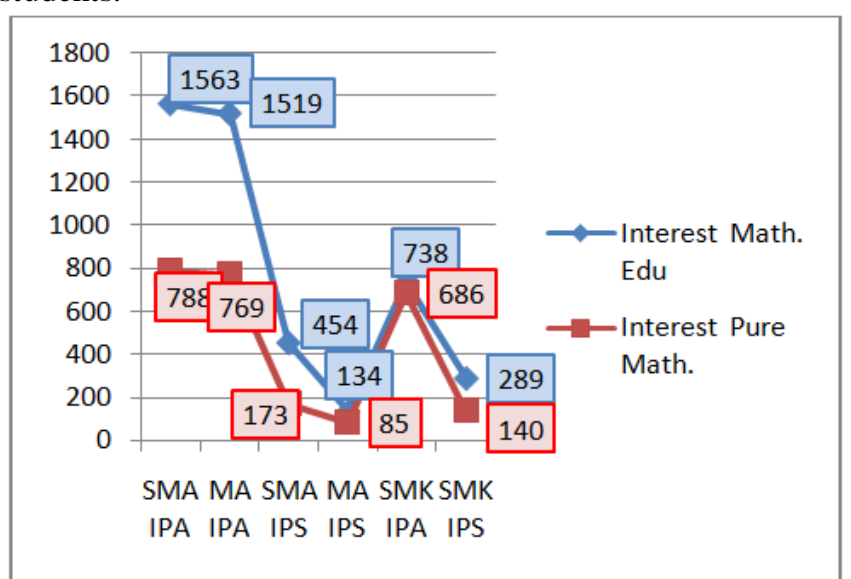

Fig. 1. Number of Applicants of Mathematics Education and Pure Mathematics Study Program
The probability ratio values of prospective students who interested in mathematics education and pure mathematics based on a different senior high school background are shown in Table 6. Those values used the odds ratio.

The odds ratio value $(\hat{\theta})$ can be compute for each of a senior high school backround that is compared to SMA IPA background as a reference category in Table 6 . The odds ratio value for the SMA IPS background is 2.2. This value means the prospective students who came from SMA IPS in backgroound are two times more likely to be interesting in mathematics education than the prospective students who came from SMA IPA in background. For all of the backgrounds of those senior high school in Table 6 shows that the odds ratio values are more than value of 1 . That means the prospective students tend to be more interested in the mathematics education study program than the pure mathematics, except for a SMK IPA background.

\section{CONCLUSION AND SUGGESTION}

The research results show that the most interested study programs by prospective students in 2014 for the field of science-and-technology were Medical Education, Informatics Engineering Education, and Civil Engineering. While in the field of social-and-humanities were Elementary Teacher Education, English Study, Accounting, Law, and Management. For that reason, the expansion opportunities study to higher education would be better if it considers the interest of students in those study programs. The capacity of those study programs can be considered to be increased, and the expansion of employment can be considered to be planned.

The prospective students tend to be more interesting in mathematics education study program than interesting in pure mathematics study program. Hence, the election probability of mathematics education study program tends to be greater than the election probability of pure mathematics study program for various senior high school backgrounds. It becomes interesting to do further research in terms of finding the influential factors of interest student in study programs in public higher education primarily mathematics education and pure mathematics study programs. 
Table 6. The Probability Ratio Values of Prospective Students for various backgrounds in Senior High School

\begin{tabular}{llccc}
\multicolumn{5}{c}{ for various backgrounds in Senior High School } \\
\hline No, & $\begin{array}{c}\text { Senior High School } \\
\text { Background }\end{array}$ & $\begin{array}{c}\text { The Number of Prospective } \\
\text { Students } \\
\text { Mathematics } \\
\text { Education }\end{array}$ & $\begin{array}{c}\text { Pure } \\
\text { Mathematics }\end{array}$ & $\begin{array}{c}\text { Odds } \\
\text { Ratio }\end{array}$ \\
1 & SMA IPS & 454 & 173 & 2.2 \\
2 & MA IPA & 1519 & 769 & 1.6 \\
3 & MA IPS & 134 & 85 & 1.3 \\
4 & SMK IPA & 738 & 686 & 0.9 \\
5 & SMK IPS & 289 & 140 & 1.7 \\
6 & SMA IPA & 6424 & 5311 & \\
\hline \multicolumn{5}{r}{}
\end{tabular}

One of those factors can be observed with regard to the student motivation. Motivation in education research has been classified into intrinsic and extrinsic motivation [15], such as "push" and "pull" [16] [17]. Other influence factors can be observed such as attitude towards [18], socio-economic family.

\section{REFERENCES}

[1] Pemerintah RI, "Undang-Undang Dasar Negara Republik Indonesia Tahun 1945 Amandemen," 2002.

[2] L. Purnastuti, "Externalities and the Social Return to Education in Indonesia," vol. 18, no. 1, p. 55281, 2015.

[3] V. Kushnarenko and S. Knutson, "Internationalization of Higher Education in Post-Soviet Ukraine," Int. High. Educ., no. 75, pp. 1-6, 2014.

[4] J. Priebe, F. Howel, and V. Sari, "Poverty and the Labour Market in Indonesia: Employment Trends Across the Wealth Distribution," SSRN, vol. October, 1, 2014.

[5] J. Knight, "Trade Creep : The Implication Policy," Int. Hhigher Educ., vol. 28, pp. 5-7, 2002.

[6] I. Ben-david and Y. Iram, "Access to Higher Education: The Israeli Case," pp. 27-28, 2014.

[7] E. Lima, R. M. Lopes, V. Nassif, and D. Silva, "Contributions Considering Brazilian Challenges *," J. Small Bussiness Manag., pp. $1-19,2014$.

[8] OECD, Education indicators focus, no. February. 2013, pp. 1-4.

[9] OECD, How are university students changing?, vol. 06, no. 15. 2013, pp. $1-4$.
[10] R. M. Purnagunawan and V. Firmana, "Labor market development in Indonesia Has it been for all? Labor market development in Indonesia Has it been for all ?," Bandung, 2013.

[11] S. Maryati, "Dinamika pengangguran terdidik: Tantangan menuju bonus demografi di Indonesia," J. Econ. Econ. Educ., 2015.

[12] Y. Ye, Q. Wu, J. Zhexue, M. K. Ng, and X. Li, "Stratified sampling for feature subspace selection in random forests for high dimensional data," Pattern Recognit., vol. 46, no. 3, pp. 769-787, 2013.

[13] S. Dutta, "Science Direct A look at the various ratios in medicine e risk ratio, odds ratio and likelihood ratio," Indian J. Rheumatol., vol. 9, no. 3, pp. 136-140, 2014.

[14] A. Agresti, Categorical Data Analysis, Second Ed. New Jersey: A John Wiley \& Sons, Inc, Publication, 2002.

[15] K. C. Williams and C. C. Williams, "Five key ingredients for improving student motivation," Res. High. Educ. J., vol. August, pp. 123, 2011.

[16] S. Z. Ahmad and F. R. Buchanan, "Studies in Higher Education Motivation factors in students decision to study at international branch campuses in Malaysia," vol. 5079, no. September, 2015.

[17] S. Wilkins, M. Stephens, and J. Huisman, "Student satisfaction and student perceptions of quality at international branch campuses in the United Arab Emirates," J. High. Educ. Policy Manag., vol. 34, no. 5, pp. 543-556, 2012.

[18] A. Mobarakabadi, M. Shamsi, and M. Najafianzadeh, "Health Student Attitude towards Their Field of Study and Study and Future Career in Health Faculty of Arak University of Medical Sciences, Iran," J. Med. Educ. Dev. Cent., vol. 11(2), pp. 280-285, 2014. 